\title{
A GEODYNAMIC MODEL FOR THE FORMATION OF THE NORTH ASIAN CRATON IN THE EARLY PRECAMBRIAN
}

\author{
Alexander P. Smelov, Vladimir F. Timofeev and Albert I. Zaitsev
}

Diamond and Precious Metal Geology Institute, SB of RAS, Yakutsk, Russia

\section{INTRODUCTION}

The North Asian craton is one of the largest Precambrian continental fragments in the present - day geologic mosaic of Asia. The craton includes an ancient platform and outer zones (fold-and-thrust belts) of contiguous orogenic belts. The platform and outer zones of the orogenic belts have the same Precambrian crystalline basement, and thick, deformed sedimentary sequences overlapping the basement of the outer zones that laterally grade into synchronous formations of the ancient platform cover. The North Asia Craton (Kosygin et al., 1964) includes the Siberian Platform and the variously-aged Verkhoyansk, Baikal-Patom, Yenisey Ridge and Southern Taimyr marginal fold-and-thrust belts. The outer zones of the orogenic belts are separated from the platform by frontal thrusts or frontal monoclines.

In some areas of the North Asian craton large primary and placer diamond deposits have been discovered, hence establishing peculiarities of the structure and tectonic evolution of the crystalline basement is very important for predicting new diamond deposits.

The study of the recently obtained data on the composition of rocks from xenoliths of kimberlite pipes and deep borehole cores, their $\mathrm{Sm} / \mathrm{Nd}$ model ages (Kovach et al., 2000), correlation with the data available for the AldanStanovoy and Anabar shields and the Olenek analysis, and on the results of magnetic anomalies allowed to make a new tectonic map of the basement of the North Asia craton (fig. 1). The scheme differs significantly from the earlier ones (Rosen et al., 1994; and athers).

\section{GENERAL STRUCTURE OF THE BASEMENT}

The main tectonic units of the craton basement are the Archean West Yakut and East Yakut cratons dated at 2.6-2.5 $\mathrm{Ga}$, the Paleoproterozoic Daldyn-Aldan and KhapchanUchur, Sharizhalgay-Nerecha and Stanovoy orogenic belts 2.1-1.9 Ga old, and the Mesoproterozoic Lena-Aldan orogenic belt dated at 1.4-1.0 Ga, and Paleoproterozoic, Mesoproterozoic and Neoproterozoic rifts.

\section{Archean cratons}

The West Yakut craton includes the West Aldan granitegreenstone composite terrane with the age of 3.2-2.6 Ga and the Tunguska tonalite-trondhjemite gneiss terrane under the platform cover. Xenoliths of the Mir kimberlite pipe contain amphibolites with a model $\mathrm{Nd}$ age of 3.4-2.6 Ga. Only one of the boreholes has exposed granite with the age of $2.2 \mathrm{Ga}$. The East Yakut craton is delineated conventionally. It includes the Batomga granite-greenstone terrane of the Aldan-Stanovoy shield and the Tyryn and Berekte tonalitetrondhjemite gneiss terranes delineated from aeromagnetic data. Weakly metamorphosed rock units of the Olenek uplift are assumed to lie over the crystalline complexes of the Berekte terrane and have the age of metamorphism to 1.98 $\mathrm{Ga}$. They are coeval to the Udokan Series of the West Aldan composite terrane.

\section{Paleoproterozoic orogenic belts}

The Daldyn-Aldan orogenic belt is located in the central part of the North Asian craton between the Archean cratons and has a sublongitudinal strike. This orogenic belt includes the Daldyn terrane of the Anabar shield, the more southerly Tyung terrane occurring beneath the platform cover, as well as the Nimnyr and Sutam terranes of the Aldan-Stanovoy shield. The terranes are composed of granite gneiss, charnockite gneiss, enderbite gneiss, diorite gneiss, and granodiorite gneiss. The main tectonic and metamorphic events are believed to have occurred at 2.1-1.9 Ga (Smelov et al, 1998; Rosen et al., 1994). The presence of felsic orthogneisses in the Daldyn, Nimnyr, and Sutam terranes indicate Archean and Paleoproterozoic high-temperature metamorphism (3.0-2.3 Ga). The Tyung terrane is generally thought to be a fragment of an Archean craton (Shatskiy et al., 1998). However, the analysis of $\mathrm{Sm} / \mathrm{Nd}$ isotopic ages showed that metamorphic rock xenoliths in the kimberlite pipes of the Tyung terrane include two rock types. The first are garnet-amphibole-clinopyroxene and amphibole crystalline schists with $\mathrm{T}_{\mathrm{Nd}}(\mathrm{DM})$ values ranging from 3.3 to $2.9 \mathrm{Ga}$. The second type includes amphibole-two-pyroxene schists with a $\mathrm{Nd}$ model age of $2.1 \mathrm{Ga}$. The latter value is close to $\mathrm{T}_{\mathrm{Nd}}(\mathrm{DM})$ ages of $\sim 2.5 \mathrm{Ga}$ obtained from xenoliths of eclogite-like rocks of the same kimberlite pipe. The results of petrographic and geochemical studies did not reveal any difference in the metamorphic grade and the degree of secondary alteration between the two rock types. This suggests that the continental crust of the Tyung terrane formed in two stages: in the Archean (2.9-3.3 Ga) and Paleoproterozoic (2.1-2.5 Ga). Closing of Sm-Nd isotopic 


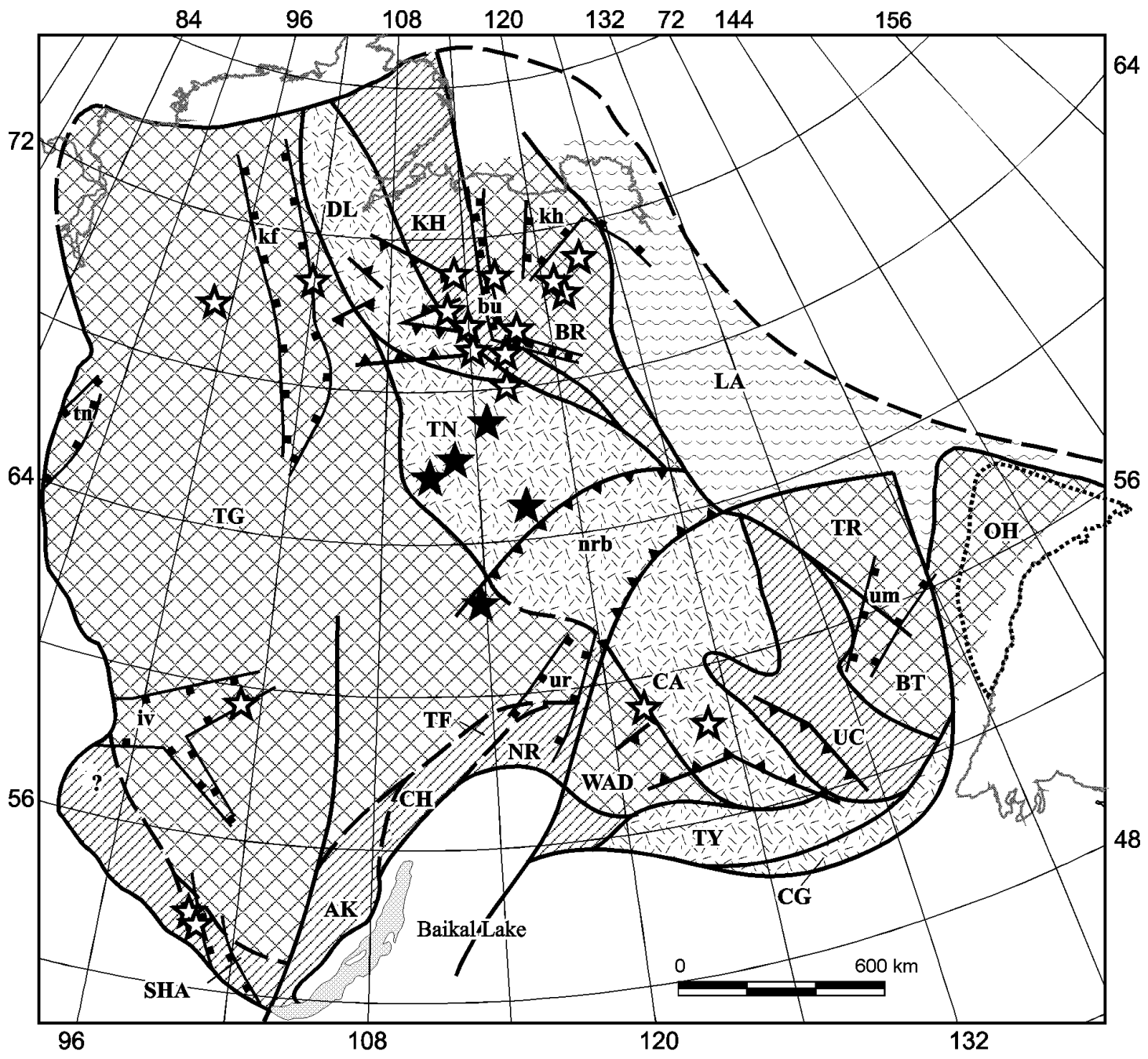

Terranes of Archean cratons:

$\$ 8$ West Yakut craton: West Aldan (WAD) and Tunguska (TG) terranes:

East Yakut craton: Batomga (BT), Berekta (BR), Okhotsk (OH) and Tyryn (TR) terranes

Terranes of the Paleoproterozoic orogenic belts:

With the reworking Archean and Paleoproterozoic crust: Daldyn-Aldan orogenic belt: Central Aldan (CA),

Daldyn (DL) and Tyung (TN) terranes; Stanovoy orogenic belt: Chogar (CG) and Tynda (TY) terranes

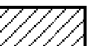

Mainly with the Paleoproterozoic crust: Khapchan-Uchur orogenic belt: Khapchan (KH) and Uchur (UC) terranes;

Sharizhalgay-Nechera orogenic belt: Akitkan (AK), Chuja (CH), Nechera (NR), Sharizhalgay (SHA), Tonod (TF) terranes

Lena-Aldan (LA) Mesoproterozoic orogenic belt

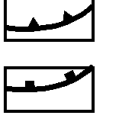

Mesoproterozoic Nyurba (nrb) rift and dike belts

Neosoproterozoic rift and dike belts: Bilir-Udzha (bu), Irkinei-Vanavar (iv), Khastakh (kh),

Kotui-Fomichev (kf), Turukhan-Khantai (tk), Ust'-Maya (um) and Ura (ur)

舟 Kimberlite pipes

Highly diamondiferous kimberlite pipes

Fig. 1. Tectonic scheme of the basement of North Asia craton

systems in minerals from garnet-clinopyroxene amphibolites of both age groups occurred at 1.7-1.88 Ga which suggests a long cooling period of the lower crustal horizons after the granulite grade metamorphism, at about $2.0 \mathrm{Ga}$ (Neymark et al., 1992).

The Khapchan-Uchur orogenic belt extends in parallels with 
the Daldyn-Aldan orogenic belt and consists of the Uchur and Khapchan granulite-paragneiss terranes. The dominating biotite plagiogneiss and gneiss, and a high-alumina of gneiss. Sm-Nd isotopic ages from paragneisses suggest that their source rocks had a Nd model age of 2.4-2.2 Ga and that the peak of metomorphic events occurred in the late Paleoproterozoic (2.2-1.9 Ga) (Rosen et al., 1994). No metamorphic events of older age have been established in terranes of this type.

The Sharizhalgay-Nechera orogenic belt occurs on the south - western margin of the North Asian craton. It is chiefly made of granulete - orthogneiss (Sharizhalgay), granulite paragneists (Nechera) and paragneists (Chuja and Tonod) terrane. The age of protoliths making up the rocks is estimated as Paleoproterozoic (2.5 - 2.4Ga) irrespective of their degree of metamorphism. Metamorphism and acid magmatism are dated of the interval of 2.1 to $1.85 \mathrm{Ga}$. Within the Sharizhalgay terrane the Onot granite greenstone terrane is mapped. The age of its composing rocks is determined as $3.2 \mathrm{Ga}$ ( Sklyarov est al., 1998).

The Stanovoy orogenic belt is located on the south-eastern margin of the North Asian craton. It includes the Tynda tonalite trondhjemite composite terrane and Chogar granulite-orthognis terrane. The Tynda terrane is made mostly of Archean rocks of different types which are combined into two complexes: the Stanovoy complex of amphibolite facies and the Larba complex of granulite facies. The Larba complex makes up relatively small tectonic slabs bounded by N-W striking faults (Rosen et al., 1994). Tectonic wedges have recently been mapped within the fault zone, which are composed of metamorphosed volcanogenic and sedimentary-volcanogenic rocks of Paleoproterozoic age (Gilyui complex). The wedges are regarded as fragments of the Mid-Gilyui, Unakha, and Nyukzha greenstone belts (Korsakov, 2000). The Stanovoy complex includes diorite-tonalite-trondhjemite gneisses, metabasites, and paragneisses. Metamorphism is of highpressure amphibolite facies. Isochronous $\mathrm{U}-\mathrm{Pb}$ ages of zircons from tonalite-trondhjemite gneisses are 2.9 and 2.7 $\mathrm{Ga}$. The age of marginal zones of zircons from the same tonalite-trondhjemite gneisses and of zircons from metabasite dikes is $1900 \mathrm{Ma}$, which is interpreted as the age of granulite and amphibolite metamorphism (Nutman et al., 1992). The Chogar Terrane is composed of high - pressure granulites aged as Mesoarchean (Karsakov, 1983).

Shear zones separating the terranes of the Archean cratons and Paleoproterozoic belts formed in the period of 2.1 to 1.8 $\mathrm{Ga}$ and can be traced with intense linear positive magnetic anomalies beneath the platform cover.

\section{Mesoproterozoic orogenic belt}

The Lena-Aldan orogenic belt has first been delineated in the structure of the North Asian craton basement (Smelov et al., 1998). It is located along the eastern margin of the craton and overlain by sedimentary rocks of the Verkhoyansk fold- paragneisses of the terrane include a two-pyroxeneamphibole gneiss and schist, marble and calciphyre, garnetand-thrust belt. The rocks are metamorphosed to greenschist and low-grade amphibolite facies. Microgneisses from the Ivanovskaya borehole underwent similar grade metamorphism. Sm-Nd isotopic studies revealed the source rocks of two age groups, 2.5-2.2 Ga and 1.4-1.0 Ga, for them. It is supposed that fragments of the belt are exposed within the limits of the Near-Kolyma uplift, northeast of the Okhotsk terrane. In the central part of the Near-Kolyma uplift a homonymous collisional zone traceable for about $400 \mathrm{~km}$ is delineated by Beus, 1992. Numerous tectonic sheets, blocks and wedges made of Paleo- and Mesoproterozoic metamorphic rocks of varying composition and origin are found in the zone. Some of the tectonic blocks are composed of greenschist facies rocks that resulted from the transformation of Mesoproterozoic carbonate-terrigenous rock sequences formed in littoral - marine and shelf conditions. Other Mesoproterozoic blocks consist of oceanic rocks (basalts, gabbroids, siliceous rocks, clay shale) metamorphosed to greenschist - low grade amphibolite facies. Metabasalts and metagabbroids often contain relics of primary porphyritic and ophitic textures and of amygdaloidal structure. Oceanic origin of the rocks is supported by the presence and chemical composition of pillow breccias composed of metabasalt globules $(1-2 \mathrm{~mm}$ to $30-40 \mathrm{~cm}$ in size) and small tuff fragments. It is supposed that the oceanic rock blocks were attached to the craton as a result of collision that had ended in the Mesoproterozoic time as evidenced by an angular unconformity at the base of the Neoproterozoic.

Thus, formation of the continental crust within the North Asia craton occurred in three stages: 1) in the Meso Neoarchean (3.1-2.6 Ga) when cratons formed; 2) in the Paleoproterozoic (2.1-1.9 Ga) when orogenic belts appeared and 3$)$ in the Mesoproterozoic $(<1.4 \mathrm{Ga})$ when orogenic belts came into existence. Each orogenic stage was changet by the formation of different-scale rift structures ( Fig. 1).

\section{A GEODYNAMIC MODEL FOR THE FORMATION OF THE NORTH ASIAN CRATON}

A model for the formation of the North Asian craton at 2.52.0, 2.0-1.6 and 1.6-1.0 Ga time intervals is proposed and substantiated in the context of plates tectonics. Paleotectonic reconstructions based on geologic and isotope data are verified by modeling the boundaries of the cratons and their relative positions at $850 \mathrm{Ma}$ (Nokleberg et al., 2000). The model is based on the assumption that in the Proterozoic the North Asian craton represented a single structure consisting of various Archean and Paleoproterozoic terranes of the Aldan-Stanovoy and Anabar shields, terranes of the buried basement of the Siberian platform, the Okhotsk and Omolon terranes, as well as metamorphic terranes of 
Mesoproterozoic age. Relative positions of the crystalline basement blocks in the Proterozoic significantly differed from those nowadays, so the North Asian craton had different outlines at the time (Nokleberg et al., 2000; Kravchinsky et al., 2001). The Sino-Korean craton was born as a single unit at $2.5 \mathrm{Ga}$ (Zhai Mingguo et al., 2000) or 1.8 Ga. The model takes into account the isotope age data obtained for the rocks of the Tynda and Chogar terranes of the Stanovoy region (Larin et al., 2002), the Okhotsk and Omolon terranes indicating that these terranes could form a part of the Sino-Korean craton.

In the Archean $(>2500 \mathrm{Ma})$, the North Asian craton was not a single structure. This was the time when the West Aldan, Tunguska, Batomga, Tyryn and Berekta granite-greenstone terranes and some complexes of the Daldyn and Central Aldan granulite-gneiss terranes were forming. The data about their mutual arrangement are missing. As to the SinoKorean craton, at least its eastern part presented a single structure at the time, probably including the Nechera, Tonod, Chuja, Tynda, Chogar, Okhotsk and Omolon terranes.

In the Paleoproterozoic (2500-2000 Ma), large granitegreenstone terranes (fragments of protocratons) of the North Asian craton began converging along strike-slip faults. Passive continental margins and microcontinents (Daldyn, Central Aldan terranes) can be reconstructed around the periphery of the terranes and along the convergent boundaries, respectively. The convergence of the SinoKorean and North Asian cratons along the strike-slip fault was accompanied with the initiation of rifts in the former. Within the Tynda terrane, the rifting process is represented by the formation of greenstone structures (Korsakov, 2000). At 2000-1900 Ma, a collision occurred between the cratons and microcontinents comprising the North Asian craton. The Daldyn-Aldan and Khapchan-Uchur orogenic belts (Daldyn, Khapchan, Central Aldan, Uchur and Tyung granulite-gneiss terranes) were formed at the time. Attachment of the SinoKorean craton to the North Asian one produced the Sharizhalgay-Nechera orogenic and Stanovoy orogenic belts. This event was accompanied with granulite metamorphism in some of the terranes (Nutman et al., 1992). The 1900-1800 Ma time interval witnessed the displacement of the Sino-Korean craton and the southern terranes of the North Asian craton relative to its northern terranes along the left-lateral srtike-slip fault. This process was probably related to the on-going formation of the supercontinent Pangea and is expressed in the emplacement of collisional granites aged at about $1.85 \mathrm{Ga}$. In the late Paleoproterozoic (1800-1600 Ma), rift basins were initiatedin parallel with the zone of the collision between the North Asian and Sino-Korean cratons. This was accompanied with subalkaline and alkaline magmatism. In the Central Aldan and West Aldan terranes, ultrabasite and carbonatite bodies were emplaced.

The Early Mesoproteozoic (1600-1300 Ma) was marked with the initiation and development of sedimentary basins (East Angarsk, Patom, Sette-Daban, Near-Kolyma, Linda) of the passive continental margins along the present-day boundaries of the North Asian craton and origination of the Nyurba rift in the inner parts of the craton (Smelov et al., 2002). Processes of rifting and formation of passive continental margins were related to the onset of the breakup of the Paleoproterozoic continent Pangea. The terranes that earlier had made a part of the Sino-Korean craton (Nechera, Tonod, Chuja, Tynda, Chogar, Okhotsk, Omolon) entered into the composition of the North Asian craton. The processes continued in the western and southern parts of the North Asian craton and in the northern part of the SinoKorean craton in the interval of 1300-1000 Ma. In the north, collision between the North Asian craton and the Mesoproterozoic continent had occurred, which was accompanied with greenschist to amphibolite facies metamorphism, emplacement of collisional granites, and formation of accretionary complexes (Near-Kolyma block). The collision was synchronous with the formation of the supercontinent Rodinia, of which the North Asian craton probably made a part till $850 \mathrm{Ma}$. The breakup of Rodinia was marked with the initiation of the Bilir-Udzha, IrkineiVanavar, Khastakh, Kotui-Fomichev, Turukhan-Khantai, Ust'-Maya, and Ura rifts and development of the passive continental margin along the northern boundary of the craton.

\section{POSITION OF KIMBERLITE FIELDS RELATIRE TO TECTONIC STRUCTURES OF THE BASEMENT}

The position of Phanerozoic kimberlite fields relative to the structures of the basementis shown in Fig. 1. Analysis of the position of Paleozoic and Mesozoic kimberlite bodies with different diamond tenor relative to the precambrian structures of the basement of the North Asian craton has revealed a certain zoning. It is expressed in that the central part of the craton contains fields of highly diamondiferous kimberlites (several carats per ton). Paleozoic and Mesozoic kimberlites in the marginal parts of the craton are poor in diamonds or barren. However, placer diamond deposits are the most widespread there. This may reflect peculiarities of tectonic evolution of the central and marginal parts of the craton. Characteristically, highly diamondiferous kimberlites are confined to the terranes of Paleoproterozoic orogenic belts $(1.9 \mathrm{Ga})$ and Archean cratons $(2.6 \mathrm{Ga})$ and are remote from the areas of wide distribution of Proterozoic rifts. No Phanerozoic diamondiferous kimberlites have yet been found within the areas of Mesoproterozoic orogenic belts. This regularity can be explained, to some extent, by the results of isotope dating of the xenoliths of mantle and alkali-ultrabasic rocks from the Yakutian diamondiferous province. According to these data tectonic - thermal events occurred within the upper mantle during the time intervals of 
$1200-1000$ and $800-600 \mathrm{Ma}$, that might result in the formation of kimberlites or convergent rocks (Zaitsev et al., 1985). These supposed epochs were probably, rather intensive in the northern part of the province, since they could provide a large-scale diamond tenor of the region (Podvysotskiy, Belov, 1995). The existence of weakly diamondiferous or barren kimberlites in the region in the following epochs may be explained by the evolution of the upper mantle source and its disappearance in a result of endogenic processes that manifested themselves on the periphery of the craton and led to the rifts formation.

\section{CONCLUSION}

The crystalline basement of the Siberian platform had formed by the time of $1.9 \mathrm{Ga}$, while that of the North Asian craton as a whole - by the time of $1.0-0.8 \mathrm{Ga}$. The Middle Paleozoic highly diamondiferous kimberlites are confined to granulite - gneiss terranes of the Early proterozoic orogenic belts $(1.9 \mathrm{Ga})$ or to cratonal terranes $(2.6 \mathrm{Ga})$ near their boundary with the former.

Middle Paleozoic and Mesozoic highly diamondiferous kimberlites are absent around the periphery of the Siberian platform in the areas that underwent intense late proterozoic tectonic - thermal reworking, which caused the destruction of the diamondiferous protolith.

It is supposed that the sources of diamond placers in the northern part of the North Asian craton have the Precambrian age and are related to rifting processes during the breakup of Rodinia.

\section{REFERENCES}

Beus, V.A., 1992. Age and geologic - petrochemical characteristics of metamorphic orthorocks of the Near-Kolyma Precambrian complex. In: Regional geodynamics and stratigraphy of the Asian part of the USSR. Leningrad, NGNPP «Aerogeologiya», pp. 65-85 ( in Russian).

Zaitsev, A.I., Nikishov, K.N., Nenashev, N.I. and Kovalskiy, V.V., 1985. Evolution of $\mathrm{Sr}$ - isotope composition in kimberlite rocks of the Yakutian province. In: Petrologic geochemicar characteristics of deep evolution of the matter of kimberlitic and basitic magmatic systems. Yakutsk, pp.13-37. (in Russian).

Karsakov, L.P., 1983. Metamorphic complexes of Priamuriye. In: Metamorphism of the Precambrian in the Baikal-Amur railway region. Leningrad: Nauka, pp. 66-97 (in Russian).

Korsakov, A.K., 2000. Tectonic environment of the formation of greenstone belts and their metallogenic specialization. Synopsis of Doct. Sci. thesis. Moscow. (in Russian).

Kosygin, Yu.A., Basharin, A.K., Berzin, N.A., Votakh, O.A., Krasil'nikov, B.N., and Parfenov, L.M., 1964. Precambrian tectonics of Siberia. Novosibirsk, Siberian Branch, U.S.S.R. Academy of Sci. (in Russian).

Kovach, V.P., Kotov, A.B., Smelov, A.P. et al., 2000. Stages of formation of the continental crust of the buried basement in the Siberian platform: Sm-Nd isotope data: Petrology,
8(4), 394 - 408 ( in Russian).

Kravchinsky et al., 2001 Kravchinsky V.A., Konstsntinov K.M. Cogne J.-P. Palaeomagnetic study of Vendian and Early Cambrian rocks of South Siberia and Central Mongolia: was the Siberian platform assembled at this time?:

Precambrian Research, 110, 61-92.

Larin, A.M., Kotov, A.B., Kovach, V.P., Glebovitskiy, V.A., et al., 2002. Stages of formation of the continental crust in the central part of the Dzhugdzhur - Stanovoy fold area ( Sm $\mathrm{Nd}$ isotope data on granitoids): Geology and Geophysics. 43(4), 395-399. (in Russian).

Neymark, L.A., Rytsk, E.Yu., Rizvanova, N.G., 1993. Hercynian age and Precambrian crustal protolith of Barguzin granitoids of the Angara-Vitim batholith: $\mathrm{U}-\mathrm{Pb}$ and $\mathrm{Sm}-\mathrm{Nd}$ isotope evidence. Doklady RAS, 331(6), 726-729. (in Russian)

Nokleberg W.J., Parfenov L.M., Monger J.W.H., Norton I.O., Khanchuk A.I., Stone D.W., Scotese C.R., Scholl D.W., Fujita K., 2000. Phanerozoic tectonic evolution of the Circum-North Pacific. Professional paper 1626. U.S. Department of the Interior, U.S.G.S.

Nutman A.P., Chernyshev I.V., Baadsgaard H. and Smelov A.P., 1992. The Aldan Shield of Siberia, USSR: the age of its Archean components and evidence for widespread reworking in the mid-Proterozoic: Precamb. Res., 54(4), 195-209.

Podvysotskiy, V.T. and Belov, E.N., 1995. Composition and formation conditions of ancient sedimentary reservoirs and diamond placers. - Yakutsk: Izd-vo YaNTS SO RAN (in Russsian).

Rosen, O.M., Condie, K.C., Natapov, L.M., and Nozhkin, A.D., 1994. Archean and Early Proterozoic evolution of the Siberian craton: a preliminary assessment, in Condie, K.C., ed., Archean crustal evolution: Amsterdam, Elsevier, pp. 411-459.

Sklyarov, E.V., Dobretsov, N.L, 1987. Metamorphism of ancient ophiolites of the Eastern Sayan. J. Geologia i Geopfizika, 2, 3-14. (in Russian)

Smelov, A.P., Kovach, V.P., Gabyshev, V.D., et al., 1998. Tectonic structure and age of the basement in the eastern part of the North Asian craton. In: Otechestvennaya Geologiya, 6,6-10. (in Russian).

Smelov A.P., Yan H., Timofeev V.F., 2002. A model for the formation of the North Asian and Sino-Korean Cratons// Central and Northeastern Asia tectonics and metallogeny. Abstracts of International Conference, Novosibirsk, pp. 2628. (in Russian).

Shatskiy, V.S., Yagouts, E., Rudnik, R.L., et al., 1998. Xenoliths of garnet granulites from the Udachnaya and Leningradskaya kimberlite pipes. In: Problems of petrology of magmatic and metamorphic rocks. Tez. dokl. mezhd. simpo. May 29-31, Novosibirsk, pp.45-46. (in Russian).

Zhai M.G., Bian A.G., Zhai T.P. , 2000. The amalgamation of supercontinent of North China Craton at the Neo-Archean and its break- up during the late Paleoproterozoic and Mesoproterozoic. Sci. China Ser D 43, 219-232.

Contact. A.P.Smelov, av.Lenina, 39, Yakutsk, Russia, 677891. E-mail: a.p.smelov@diamond.ysn.ru 